\title{
INCORPORATING TEACHING EFL READING INTO THE MODEL OF LEARNING FROM PRESENTATION FOR INDONESIAN STUDENTS
}

\author{
Nasir \\ Nahdlatul Ulama University of Lampung - Indonesia \\ (nasir_melinda@yahoo.com)
}

\begin{abstract}
Model of teaching delineates learning materials which are enacted by learners. Not only is teaching reading as a receptive skill; teaching reading is also as an integrated skill. This study aimed at describing incorporating teaching EFL reading as a receptive skill into Model of Learning from Presentation (MLP) as visual and oral-based teaching at teachers' training of elementary school of Nahdlatul Ulama University of Lampung, Indonesia. To investigate, questionnaire and interview were deployed as research instruments in this descriptive qualitative study. The findings of questionnaires, which explored three aspects including graphic organizer as a visual aspect, oral presentation as a oral aspect, and students' perceptions for each aspect, to 24 students showed (1) almost all students (87\%) stated MLP enabled them to learn graphic organizers which induced ease of presentation, (2) many students (75\%) stated MLP enabled them to practice oral presentation which could foster their speaking and writing skills, (3) all students (100\%) stated $M L P$ reinforced their responsibility for material mastery and presentation delivery. These were confirmed by the findings of interviews to 5 students that revealed (1) their needs for graphic organizer in MLP to elude inaccurate diagram construction; (2), their needs for oral presentation in MLP to enhance linguistic knowledge and text comprehension, (3) their needs of MLP to deliver learning materials
\end{abstract}

Keywords: model of learning from presentation, teaching EFL reading, graphic organizer, oral presentation

\section{INTRODUCTION}

Not only is learning reading as a decoding process by interpreting the meanings of symbols; learning reading is also as a decoding skill by predicting skills in reading comprehension (Beck\&Juel, 1995:2). Teaching reading is as decoding skills by including instruction of vocabulary, grammar, and writing (Wren, 2009:1) and as visual displays by presenting Graphic Organizers (Hall\&Strangman, 2002; Sharifi, 2013:1).
Four foundations for learning to decode include (1) language development in four English skills, (2) concepts of print in convention of printed language, (3) letter recognition in alphabetical letters, and (4) phonic awareness in word sounds (Chard, Pikulski, \& Templeton, 2000:3-4).

Teaching reading is as an integrated skill inasmuch as early EFL reading progress depends upon oral language developments in learning vocabulary, grammar, and 
sound system (Muaka, Bernhardt, \& Kamil, 2003:8). Oral language, which is essential to reading and writing skill, is the foundation for learning to read by understanding printed languages, namely vocabulary, grammar, and sound (Konza, 2011:1).

Model of Teaching as also Model of Learning which is employed in teaching EFL reading advocates learners in acquiring ideas, skills, and expressing. Moreover, the model of teaching delineates curriculum, courses, and instructional materials in learning environment (Joyce, Weil, \&Calhoun, 2000:6\&13).

Learning from Presentation as one of the teaching models provides concept and graph about how to display the knowledge (Gerbe \&Peron, 1995:4) which is underlain by four learning concepts including (1) visual teaching as a visual image language, which can enhance students' reading and writing skill, by producing a visual language (Timothy, 2009:2), (2) visual organizers learning that cover Graphic Organizers and advance organizers (Kang, 2004:58-59), (3) oral presentation as a short talk for topic that enables students to present his views (the Learning Centre, 2010:1), (4) oral language development which builds phonological system by combining words with sounds (Konza, 2011:1$3)$.

Advance organizers that deals with subject matter, cognitive structure, and active reception learning (Joyce, Weil, \&Calhoun, 2000:255) were used to introduce material by bridging the gap between what the learner has already known and what to need to learn (Ausubel,
1977:168). Graphic Organizers as knowledge of concept maps and cognitive organizer by displaying visual and graphic presentation illustrate the relationships between facts and ideas in learning task (Hall \& Strangman, 2002:1). Graphic Organizers as a graphic presentation are one of the parts of the types of Advance Organizers (NCREL, 1995:2).

A study by Hamra and Syatriana (2010:34) about Indonesian students' English problem uncovered their learning reading difficulties included vocabularies, pronunciation, grammar, and reading strategy. Bernhardt (2013:3-5) found four students' improvements in reading skill by Graphic Organizer covered identifying detailed information, making inferences, constructing text organization (comparing-contrast text), and retelling oral activity as Graphic Organizer allowed students to arrange information easily. Davaei and Talebinezhad (2012:2048-2049) found Advance Organizers could activate learners' background knowledge about topic for developing level of their reading comprehension; and had better learners' reading comprehension performance when listening and reading to the main text in tandem.

Oral presentation as one-way communication involves students 'role of speaking and writing skill that focus on appropriateness and accuracy of the language (Dickerson,2008:1). Bankowski (2010:189) found oral presentation allowed students to have high motivation, practice, and demonstrate newly acquired skill about what they have learned and their prior knowledge. 


\section{Literature Review}

In working with this study, the related theories are taken from Mohammadi, Moenikia, \& Babelan (2010: 4671) who found Graphic Advance Organizer effectively promote English language learning as Second Language since the post test mean score of experimental group(16.18) was higher than that of control group (14.86).

Learning to read relates to process, roles, and foundation. Two processes of learning to read comprise (1) decoding process by identifying unfamiliar words and developing vocabulary, comprehension process by attaching meaning to words, sentences, paragraph, and text (Donoghue, 2009:157).

Two decoding roles in learning to read cover (1) decoding process by interpreting reading and word recognition (familiar words) and word attack (unfamiliar words), (2) decoding skill by predicting reading comprehension skills such as vocabularies and knowledge of a text (Beck \& Juel,2002: 1-4).

Four foundations to decode include firstly, oral language development that is acquired from listening and speaking skill and written language development that is acquired from reading and writing skill (Chard, Pikulski, \& Templeton,2000:3-4). Secondly, concept of print for convention of printed words which delineates children need to know written text from left to right that corresponded between words and sound (Alliance documents, 1998; Chard, Pikulski, \& Templeton,2000: 4).

Thirdly, letter recognitions as orthographic familiarities that were
Incorporating Teaching EFL Reading Into The Model Of Learning From Presentation for Indonesian Students

recognized by young readers in learning to read depended on speed and accuracy(Adam, 1990; Chard, Pikulski, \& Templeton,2000: 4). Fourthly, phonemic awareness is a sounding printed letter in spoken words ( Chard, Pikulski, \& Templeton,2000: 4).

Oral language in reading skill establishes listening skill, phonological awareness, phonics, vocabulary, fluency, and comprehension (Konza, 2011:2). Juel (1988: 440-443) found well-read students, in decoding skills, were better than little-read students inasmuch as (1) well-read students were able to read more words than little-read students were; (2), wellread students possessed better word recognition and vocabulary knowledge as well as reading and listening comprehension than littleread students did; (3), well-read students were able to orally tell author and plots of story; meanwhile, little-read students were only could supply information. Lesgold \& Resnickk (1984; Beck \& Juel; 2002:3) found significant relationship between linguistic awareness and reading achievement.

Two aspects that advocate oral language development in the early reading development skills include (1) principles of oral language development that include speech delays with hearing assessment, personal, and social relationship establishment, 3-5 seconds information process for thinking;(2), principles of teacher language that include students' correction of language use model and student's understanding based on students' needs for language learning( Konzan,2011:1-3). Hill \& Launder (2009:7-8) found significant 
relationship in oral language between phonological ability and reading ability; however, insignificant relationship between receptive vocabulary and reading ability.

Three basic elements of teaching oral presentation that include (1) students have to possess field knowledge; (2), students have to be able to appropriately organize their ideas in logical sequences; (3), students have to possess good grammatical competence and the ability to deliver their talk in presentation (King, 2002; Cadman \& Shu-Hui Yu, 2009:2).

Three students' problem of orally organizing and communicating their ideas that include (1) learners have insufficient practice and opportunities to speak, (2) learners are unfamiliar with skills and strategy to develop oral language, (3) learners have little opportunity to cohesively and coherently arrange their ideas in oral language (Mazdayasna, 2012:23).

Three communication modes in oral presentation include (1) interpretative mode as one-way communication to employ students 'listening and reading skill, (2) presentational mode as one-way communication to employ students speaking and writing skill by highlighting appropriateness and accuracy, (3) interpersonal mode as two-way communication by discussing and modifying the meaning of oral or written exchange (Dickerson, L,J. 2008:1).

Miles (2009:105) found oral presentation could enhance students' oral communication skills consisting of speaking skill, confidence, and challenge to speak which allowed students to communicate their ideas by using their speaking skills.
Moreover, Dekdouk (2013:47) found four students' English improvements from oral presentation classroom included interesting learning activity, English grammar $(41 \%)$, pronunciation (67.5\%), vocabulary (38\%) inasmuch as oral presentation assisted students to employ English accurately.

Four elements in visual teaching to understand and create visual message include (1) fullspectrum visual literacy by using visual encoding to expresses visual ideas to translate the meaning of visual imaginary, (2) active and performance- based learning by interfacing visual imaginary with real world, (3) dynamic translation by expressing ideas into text presentation, (4) multidisciplinary approach to communicate a new information by using visual literacy, visual art, and visual skills (Timothy ,2009:3-4).

Yunus, Salehi \& John (2013:115-116) found visual teaching enabled students to easily understand the abstract ideas in the texts, to enhance their performance, and to create enjoyable environment since visual teaching as helpful device facilitated students' understanding of the text.

Learning from Presentation by Ausibel is underpinned by three meaningful learning include (1) curriculum for how knowledge that is organized, (2) learning for how minds that works for new information, (3) instruction for how teachers that apply curriculum and learning (Joyce, Weil, \&Calhoun, 2000:249\&255).

Two orientations of Learning from Presentation model cover (1) organizing information as a parallel between subject matter and 
Incorporating Teaching EFL Reading Into The Model Of Learning From Presentation for Indonesian Students

knowledge organization, (2) implication for teaching as introductory materials to strengthen cognitive structure for new information (Joyce, Weil, \&Calhoun, 2000:250\&253).

Advance Organizers are presented by Graphic Organizers display which comprise two types including (1) Advance Organizers as a new topic introduction by giving students overview and new information about what the students already know by illustrating a new information organization,

Advance Organizer as a task planner design by displaying organizational cues ( Ylvisaker, Hibbard \& Timothy,2006:1).

Mohammadi, Moenikia, \& Babelan (2010: 4671) found Graphic Advance Organizer effectively promote English language learning as Second Language since the post test mean score of experimental group(16.18) was higher than that of control group (14.86).

Graphic Organizers are the combination between linguistic modes and non-linguistic modes to store information (NCREL, 1995:3). Graphic Organizers as a visual representation of knowledge comprise essential aspects which are displayed into pattern organizers using labels (Broomley, DeVitis, \& Modlo,1999;

Education Department,2001:3).

Graphic Organizers as information display of concise way highlight the organization which relates among concepts (Education Department, 2001:3). Types of Graphic Organizers are illustrated in Figure 1.
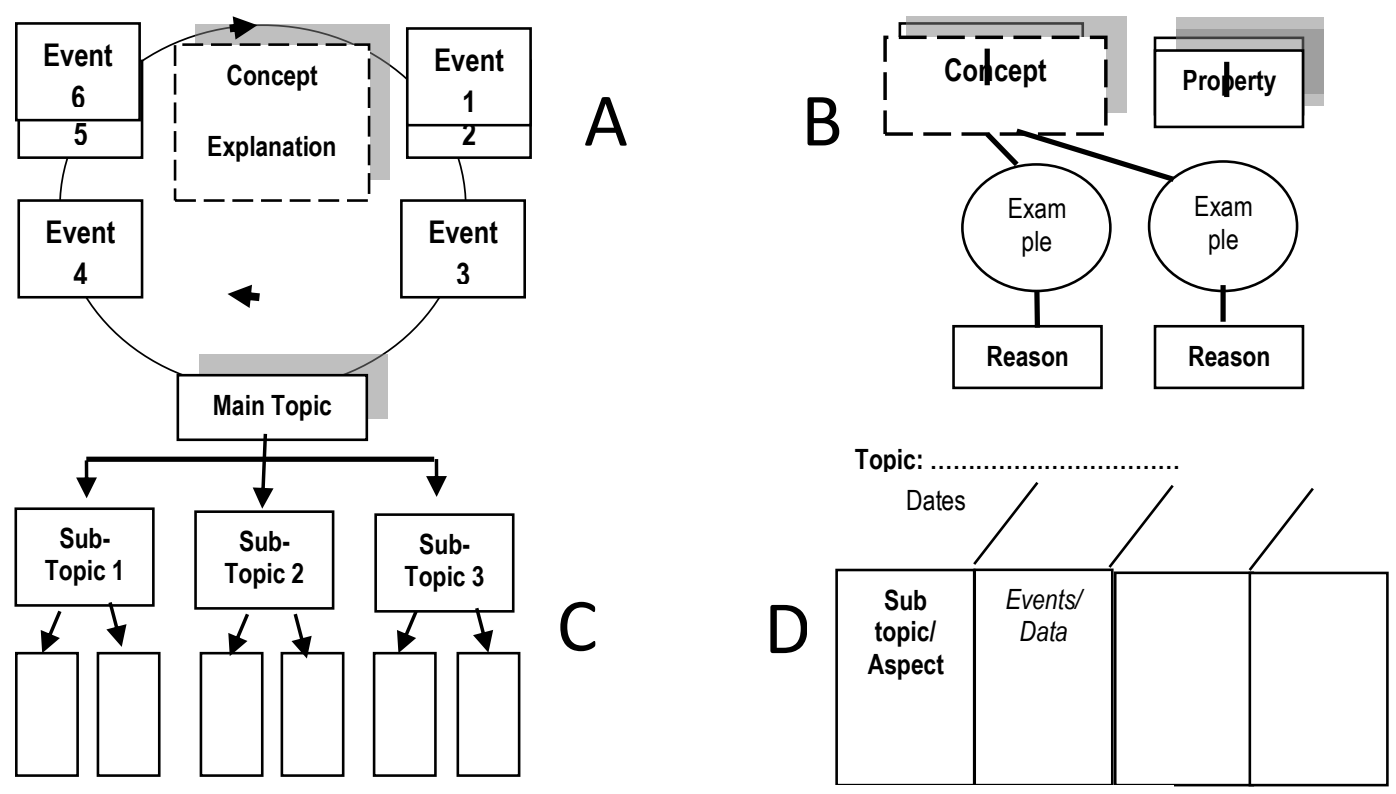

Figure 1. Basic Categories of Graphic Organizers

Four basic categories from types of graphic organizers include (1) cyclical organizer that represents A to understand sequences of events;
(2), concept definition map that represents B to focus on the main components of definition; (3), hierarchy diagram that represents $\mathrm{C}$ 
to see super ordinate and subordinate category to clarify the relationship between concepts; (4) multiple time that represents D to see aspects of time and its influences on each other.

Ozturk (2012:43) found (1) Graphic Organizers had a positive effect on the learners' reading comprehension achievement inasmuch as the mean of experimental group (18.89) was much higher than of control group (12.00), (2) experimental group learners were quite willing to share their Graphic Organizers with their classmates cooperatively.

\section{Method}

Deploying descriptive qualitative design in this study, which involved 24 students of teachers' training of elementary school of Nahdlatul Ulama University of Lampung, is to understand and report the characteristics of current and past situation by describing what already exists in a focus group as individuals with similar characteristics (Baudah, 2011:10). This research design to study natural and holistic phenomena included micro-level phenomenon such as interaction within the classroom 2005:163).

(Mackey\&Grass,

Semi-Structured interviews were conducted based on Focus Group Interview method, which typically consists of from four to six person to collect shared understanding from several individuals and get specific people's views (Creswell, 2012:218), that were used to probe predetermined questions to collect in-depth information (Easwaramoorthy \& Zarinpoush, 2006:1). Those four persons were selected purposively under the consideration of accessibility. Meaning that the researcher easily accessed the persons via phoning when they were needed to be interviewed. The interviews were conducted in the place where they were comfortable and ready to conduct the interview.

$$
\text { Specific Open Ended }
$$

questionnaires, which were distributed based on Group Administration method to achieve language learners studying (Dornyei,2003:82), were to gain information that is followed up with reasons (Dornyei,2003:48). Accordingly, questionnaires were distributed to 24 students; meanwhile, interviews were conducted to four students. The questionnaires were asking about not only teaching reading as a receptive skill but teaching reading as an integrated skill as well. The qustionnaires also asked the students about their response relating to the incorporation of teaching EFL reading using Model of Learning from Presentation (MLP) as visual and oral. While observation was the main research instrument, interview was used to verify or support the data gained through observation.

Interview and questionnaire, of which each comprises behavior aspect to obtain learners' habit and attitudinal aspect to explore learners' opinion (Dornyei,2003:8), were analyzed according to Descriptive Coding for interview by categorizing students' opinions (Saldana, 2013:7) and Coding Frame for questionnaire by providing categories for cases (Dornyei,2003:99).

\section{FINDINGS AND DISCUSSION}

Three aspects, which emphasize on Graphic Organizer 
construction, oral presentation, and students 'facts and perceptions for the two aspects, of the findings on the learning from presentation model of teaching are presented in Table 1.

Tabel 1. The Findings on Learning from Presentation in Three Aspects

\begin{tabular}{|c|c|c|c|}
\hline No & Question Concerns & Yes & No \\
\hline 1. & $\begin{array}{l}\text { Students' learning experience about learning from } \\
\text { presentation. }\end{array}$ & $71 \%$ & $29 \%$ \\
\hline 2. & $\begin{array}{l}\text { Students' difficulties in constructing Graphic Organizer } \\
\text { diagram }\end{array}$ & $67 \%$ & $33 \%$ \\
\hline 3. & $\begin{array}{l}\text { Students' text comprehension to construct Graphic } \\
\text { Organizer diagram }\end{array}$ & $100 \%$ & $0 \%$ \\
\hline 4. & Students' facility of learning from presentation using & & \\
\hline & Graphic Organizer diagram. & $87 \%$ & $13 \% \%$ \\
\hline 5. & $\begin{array}{l}\text { Students' facility to catch explanation using Graphic } \\
\text { Organizer diagram. }\end{array}$ & $78 \%$ & $22 \%$ \\
\hline 6. & $\begin{array}{l}\text { Students' difficulty to explain material using Graphic } \\
\text { Organizer diagram. }\end{array}$ & $75 \%$ & $25 \%$ \\
\hline 7. & $\begin{array}{l}\text { Students' difficulty to explain material using linguistic } \\
\text { aspect }\end{array}$ & $100 \%$ & $0 \%$ \\
\hline 8. & $\begin{array}{l}\text { Students' perceptions material mastery when } \\
\text { performing presentation. }\end{array}$ & $100 \%$ & $0 \%$ \\
\hline 9. & $\begin{array}{l}\text { Students' perceptions for readiness to deliver } \\
\text { presentation. }\end{array}$ & $100 \%$ & $0 \%$ \\
\hline 10. & $\begin{array}{l}\text { Students' perceptions for responsibility to master } \\
\text { material and deliver presentation. }\end{array}$ & $100 \%$ & $0 \%$ \\
\hline
\end{tabular}

Four questions, namely question 2,3,4, and 5, from Graphic Organizers aspect, two question, namely question 6 and 7, from Oral Presentation aspect, and four questions, namely question 8,9 , and 10 to explore students' perception for the two aspects were endorsed by each reason. But, question1 void of being equipped by reason was to confirm the students' experience about learning from presentation.

Also, three aspects in students' interview comprise Graphic Organizer diagram, oral language, and perceptions of the two aspects are presented in Table 2 . which comprise seven questions. The interview questions were as follows: to explore whether or not (1) they have ever joined Learning English by presentation; (2), they have difficulty in constructing diagram; (3), the feel easy to deliver presentation; (4), they receive explanation from presentation; (5), they need to fully comprehend a text before constructing diagram; (6) they have difficulty in using English to deliver presentation;(7), they have responsibility for material mastery in delivering presentation. The findings on the three aspects 
Table 2. The Descriptive Coding from Interview

\begin{tabular}{|c|c|c|}
\hline No & Responses & Descriptive Coding \\
\hline 1. & $\begin{array}{l}\text { 1.I have ever joined studying through presentation } \\
\text { in front of the class; but used Indonesian language }\end{array}$ & $\begin{array}{l}\text { ISSUE OF } \\
\text { PRESENTATION }\end{array}$ \\
\hline 2. & $\begin{array}{l}{ }^{2} \text { I have problem when I will make diagram } \\
\text { because I must understand the reading text. } \\
\text { sometimes, it is very hard to understand the text. }\end{array}$ & $\begin{array}{l}\text { STUDENTS } \\
\text { READING } \\
\text { COMPREHENSION } \\
\text { TOWARDS } \\
\text { DIAGRAM }\end{array}$ \\
\hline 3 & $\begin{array}{l}\text { 3I feel easy to explain reading material using } \\
\text { diagram because the diagram is the summary of } \\
\text { information }\end{array}$ & $\begin{array}{l}\text { EASY } \\
\text { EXPLANATION } \\
\text { USING DIAGRAM }\end{array}$ \\
\hline 4. & $\begin{array}{l}{ }^{4} \text { I feel very easy to get information by diagram } \\
\text { when my friend explains content of reading because } \\
\text { the diagram gives summary of information }\end{array}$ & $\begin{array}{l}\text { EASY } \\
\text { EXPLANATION } \\
\text { USING DIAGRAM }\end{array}$ \\
\hline 5 & $\begin{array}{l}{ }^{5} \text { Yes, of course, I must understand the reading text } \\
\text { first before I make diagram because if I do not } \\
\text { understand the content of reading text, my diagram } \\
\text { will be incorrect and making diagram need an } \\
\text { understanding. }\end{array}$ & $\begin{array}{l}\text { READING } \\
\text { COMPREHENSION } \\
\text { FOR DIAGRAM }\end{array}$ \\
\hline 6. & $\begin{array}{l}\text { 6Yes, I still have problem in English when I have } \\
\text { presentation because my problem is about my the } \\
\text { meaning of words, how to pronounce words, and } \\
\text { grammar. }\end{array}$ & $\begin{array}{l}\text { STUDENTS' } \\
\text { ENGLISH } \\
\text { PROBLEM }\end{array}$ \\
\hline 7. & $\begin{array}{l}{ }^{7} \text { Yes, I must have responsibility in my } \\
\text { presentation because I must master the materials, } \\
\text { diagram, and how deliver presentation to avoid } \\
\text { confusion. }\end{array}$ & $\begin{array}{c}\text { STUDENTS' } \\
\text { RESPONSIBILITY } \\
\text { TO MASTER } \\
\text { MATERIALS } \\
\end{array}$ \\
\hline
\end{tabular}

Questions 2,3,4, and 5 which highlight on Graphic Organizer aspect, questions 6 and 7, which highlight on Oral Language aspects, and question 1 to explore students' experience were utilized in the interviews.
The findings on the questionnaire were confirmed with interview in each aspect. The findings on Graphic Organizer aspects were depicted in Figure2.

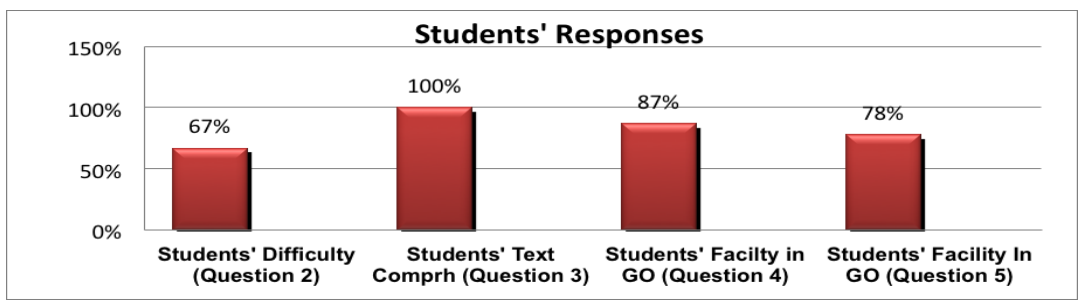

Figure 1. Responses of Graphic Organizer Aspect 
Many students (67\%) found it hard to construct Graphic Organizer diagram due to their ignorance of meaning and text content; but, only a few students $(33 \%)$ found it not hard to construct it due to their understanding of text content and keywords. These findings were confirmed by students' interview which indentified students' reading comprehension towards diagram, in which it meant that they needed to comprehend the text before constructing diagram. The results of these findings were endorsed by Ausibel (1977:168) who stated constructing Advance Organizers allowed students to bridge the gap between what the learner has already known and what to need to learn.

All students (100\%) stated they need to fully comprehend text to construct Graphic Organizer diagram due to text difficulty to find conclusion and keyword. These findings were affirmed by students' interview which identified reading comprehension for diagram construction, in which it revealed that the students needed to fully understand text to elude constructing diagram incorrectly. The results of the findings were confirmed by Joyce, Weil, \&Calhoun ( 2000:249\&255) , NCREL (1995:3), and by the study by Davaei \& Talebinezhad (2012:2048-2049). Joyce, Weil, \&Calhoun ( 2000:249\&255) asserted that three Ausibel's meaning verbal learning in learning from presentation dealing with how knowledge is organized, how minds work for information, and teaching applies curriculum and learning. NCREL (1995:3) portrayed Graphic Organizers store information which emanate from linguistic and non-linguistic modes. Davaei \&
Incorporating Teaching EFL Reading Into The Model Of Learning From Presentation for Indonesian Students

Talebinezhad (2012:2048-2049) found Advance Organizers could activate learners' background knowledge about topic to evolve reading comprehension level when listening and reading.

Almost all students (87\%) found it easy to explain learning material by utilizing Graphic Organizer diagram in English due to its simplicity, conciseness, and information representation; meanwhile, only a few students $(13 \%)$ found it difficult due to ignorance of meaning and vocabulary. These findings were confirmed by students' interview which identify easy explanation in using diagram in which it revealed that the diagram was the text summary. The results of the findings were confirmed by Ausubel (1977:168), Broomley, DeVitis, \& Modlo (1999), Ylvisaker, Hibbard \& Timothy (2006), Education Department, (2001), and by study by Yunus, Salehi, and John (2013:115116). Ausibel (1977:168) stated Advance Organizer diagram allowed students to bridge between students' knowledge and students, learning need. Broomley, DeVitis, \& Modlo (1999) asserted Graphic Organizer as visual knowledge to display by using labels. Ylvisaker, Hibbard \& Timothy (2006:1) proposed two types of Graphic Organizers as a new topic introduction and as a task planner by displaying the diagram. Education Department (2001:3) asserted Graphic Organizers presented concise way to display concept organization. Yunus, Salehi, and John (2013:115-116) found Graphic Organizer diagram as a visual teaching allowed students to understand abstract ideas in the text and create enjoyable environment. 
Most students (78\%) found it easy to understand text content material explanation by using Graphic Organizer in English due to the facility of whole text explanation from the and information simplicity from a text; but, only a few students $(22 \%)$ found it difficult due their ignorance of vocabulary and meaning. These findings were affirmed by students' interview which uncover easy explanation in using diagram, in which it revealed that the diagram was the text summary. The results of the findings were confirmed by Joyce, Weil, \&Calhoun (2000), Gangwer (2009), Dickerson (L,J. 2008:1), study by Yunus, Salehi, and John (2013), and Bernhardt (2013). Joyce, Weil, \&Calhoun (2000:250\&253) assert two orientations of learning from presentation are by organizing subject matter and knowledge and strengthening cognitive structure for a new information. Gangwer (2009:3-4) states elements of visual teaching are by expressing visual ideas in the text presentation. Dickerson (L,J. 2008:1) asserted interpretative mode was used to advocate students' listening and reading skill. Yunus, Salehi \& John (2013:115-116) found visual teaching enabled learners to understand the abstract ideas from text easily. Bernhardt (2013:3-5) found graphic organizer diagram allowed learners to identify detailed information and oral retelling.

The findings on Oral Presentation aspects were illustrated in Figure

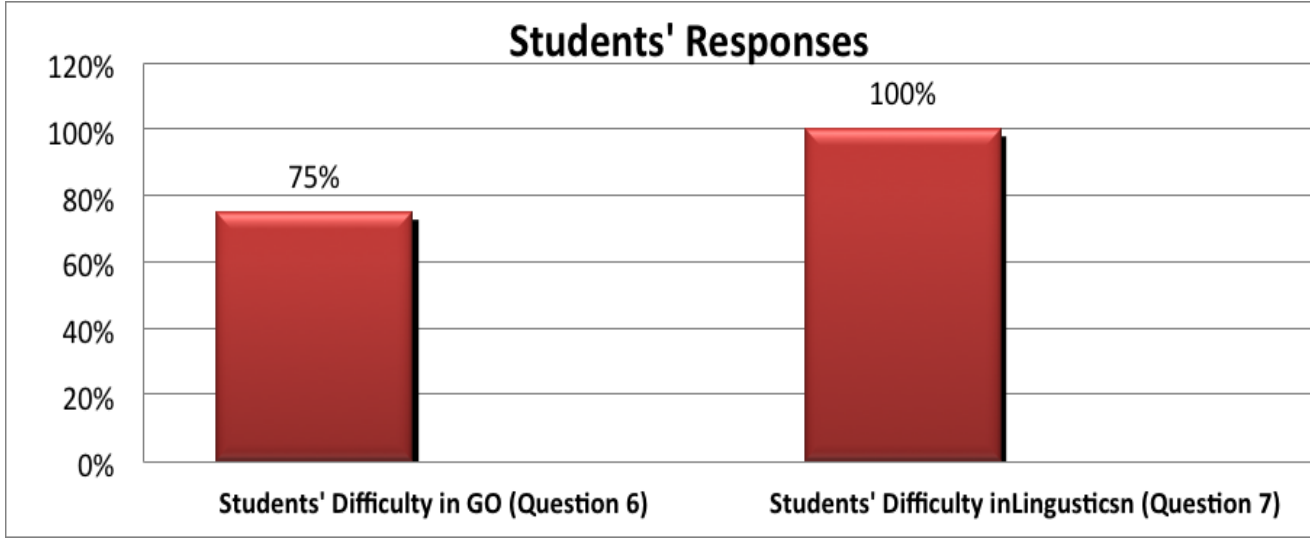

Figure 2. Responses of Oral Presentation Aspect

Many students (75\%) found it difficult to perform oral presentation due to their ignorance of vocabulary, meaning, pronunciation, and content of text; yet, only a few students (25\%) found it not hard due to their text understanding by delivering
Graphic Organizer diagram. The findings were endorsed by Konza (2011:1), Dickerson (L,J. 2008:1) and study by Miles (2009:105). Konza (2011:1) contends oral language is essential for reading and writing skills for understanding 
vocabulary, pronunciation, and grammar as a printed language. Dickerson (2008:1) asserts presentational mode was used to foster students speaking and writing skill. Miles (2009:105) found some improvements of oral presentation included speaking skill, confidence, and challenge to speak.

All students (100\%) found it difficult to perform oral presentation in English language due their ignorance of vocabulary, meaning, pronunciation, and text understanding. These findings were confirmed by students' interview which identified students' English problem, in which it revealed that their English problems covered words, vocabulary, meaning, and grammar. The results of the findings were confirmed by Donoghue (2009), Dickerson (2008), study by Hill and Launder (2009), study by Dekdouk (2013), and Hamra \& Syatriana (2010:34) Donoghue (2009:157) asserts the process of learning to read is by attaching words, sentence, paragraph, and text meaning. Dickerson (2008:1) states three modes in oral communication include interpretative mode to promote listening and reading skill and presentational mode to promote speaking and writing skill, and interpersonal mode to discuss the meaning of conversation. Hill \& Launder (2009:7-8) found the relationship between phonological ability and reading ability underlay oral language. Dekdouk (2013:47) found oral language was closely linked to interesting learning activity, English grammar, pronunciation, and vocabulary. Hamra \& Syatriana (2010:34) found vocabulary, pronunciation, grammar, and reading strategy were the students' learning reading problem in Indonesia.

The findings on students' perceptions of the two aspects from Learning from Presentation model were illustrated in Figure 3.

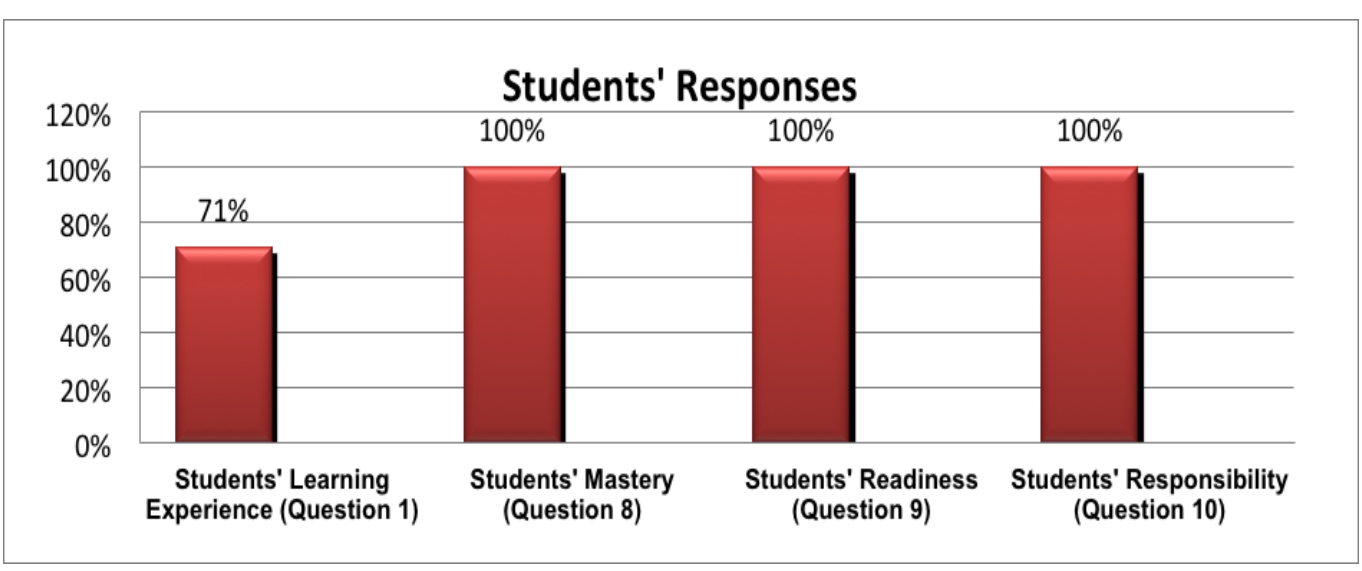

Figure 3. 'Students' Perception for Graphic Organizer and Oral Language Aspects

Many students (71\%) stated they had ever followed learning from presentation which was confirmed by students' interview uncovering issue of presentation. These findings revealed that that they had been familiar with learning from presentation model.

All students $(100 \%)$ stated they had to be able to master materials in oral presentation in order to be able 
to deliver presentation, respond questions and avoid confusion.

All students (100\%) stated they had to be able to orally deliver presentation in English language in order to convey information, make audience understand material, and show their mastery of material.

All students (100\%) stated they had responsibility to master materials and orally convey presentation in order to be able to run oral presentation well and to avoid presentation confusion as requirement for presentation. These findings were affirmed by students' interview which uncovered students' responsibility for material mastery, in which it revealed that they needed to deliver presentation well and avoid confusion.

The results of the findings on students' ability to master, convey, and responsible for presentation were endorsed by King (2002; Cadman \& Shu-Hui Yu, 2009) and Mazdayasna ( 2012). King (2002; Cadman \& ShuHui Yu, 2009:2) proposes basic elements of oral presentation which cover learners should possess knowledge to logically organize their ideas and deliver their presentation. Mazdayasna ( 2012:23) asserts students' problem of communicating their ideas in oral language due to their inadequate practice to speak, their unfamiliarity with skill and strategy, and their minimum opportunity to cohesively and coherently arrange their ideas.

\section{CONCLUSION SUGGESTION}

AND

Learning from Presentation Model in teaching EFL reading are underlain by two learning components and three patterns of communication modes.
Two learning components in Learning from Presentation Model that are emanated from reading text include Visual-Based Learning and Oral-Based Learning. Visual-Based Learning is coupled with visual teaching concept by visualizing images, ideas, and information into presentation (Timothy, 2009) and visual Graphic Organizers by visualizing the relationship between facts and ideas into presentation (Hall \& Strangman, 2002). Oral-Based Learning is coupled with oral language development by promoting phonological awareness, phonics, vocabulary, fluency and comprehension (Konza, 2011) and oral presentation by orally delivering logical ideas based on knowledge and good grammatical competence (King, 2002; Cadman \& Shu-Hui Yu, 2009).

Three patterns of communication modes in Learning from Presentation Model in teaching EFL reading comprise interpretative, presentational, and inter personal mode. Interpretative mode is to employ students' listening skill in oral presentation and reading skill in written presentation. Presentational mode is to employ students' speaking skill in oral presentation and writing in written presentation; (3), inter personal mode is to employ the four skills via discussion.

Incorporating teaching EFL reading in Learning from Presentation Model stimulates students' VisualBased Learning to evolve language components such as vocabulary and grammar. This this model of teaching stimulates students' Oral-Based Learning to burgeon pronunciation and vocabulary as well as grammar.

Concerning learning interaction in the incorporation of teaching EFL 
Incorporating Teaching EFL Reading Into The Model Of Learning From Presentation for Indonesian Students

reading into Learning from Presentation Model, it is advisable to deem three aspects of students' learning EFL reading should be well learned include (1) linguistic knowledge to establish oral and written presentation, i.e. vocabulary, pronunciation, and grammar, (2) decoding skills for comprehension by getting essential information from text, (3) graphic organizer skills for various diagram constructions.

\section{Bibliography}

Ausubel, D,P. 1977. The Facilitation of Meaningful Verbal Learning in the Classroom. Educational Psychologist, 12 (2), 162-178.

Bankowsi, E. 2010. Developing Skills for Effective Academic Presentation in EAP. International Journal of Teaching and Learning in Higher Education., 22 (2), 187-196.

Baudah, D,J. 2011. Conducting Educational Research: Guide to completing a major project. California: Sage Publication, Inc.

Beck, I. L., \& Juel, C. 2002. The Role of Decoding in Learning To Read. American Educator, 19(2), 1-11

Bernhardt, T,M. 2014. Using Graphic Organizers to Enhance Reading Comprehension. Retrieved from http://www.csha.org/conventio n/conventionHandouts/PS $\% 20$ 18,\%20Bernhardt, \%20Using\% 20Graphic $\% 20$ Organizers $\% 20$
To\%20Enhance\%20Reading\% 20Comprehension.pdf.

Cadman, K., \& Shu, Hui, Yu. 2009. EFL learners' connection with audience in oral presentations: The significance of frame and person markers. Tesol In Context. Retrieved from http://www.tesol.org.au/files/fi les/97_Yu.Cadman3.pdf

Chard, D.J., Pikulski, J.J., \& Templeton, S. 2000. From Phonemic Awareness to Fluency: Effective Decoding Instruction in a ResearchBased Reading Program. Houngton Mifflin Company. Retrieved from: http://www.eduplace.com/sta te/author/chard_pik_temp.pd f.

Creswell, J.W. 2012. Educational Research: Planning, Conducting, and Evaluating Quantitative and Qualitative Research (4 ${ }^{\text {th }} E d$ ). Boston: Pearson Education.

Davaei, R., \& Talebinezhad, M,R. 2012. The Effect of Advance Organizers on Enhancing the Reading Comprehension of Iranian EFL Learners. Theory and Practice in Language Studies, 2 (10), 2045-2052.

Dedouk, F. 2013. The Effect of Oral Presentation on Developing EGAP Students' Communicative Competence. (Doctoral dissertation) . Retrieved from http://bu.univouargla.dz/master/pdf/Fatma 
DEKDOUK.pdf?idmemoire $=255$.

Dickerson, L,J. 2008. Assessing Oral Presentations. ICCT Coachnotes. Retrieved from http://www2.wheaton.edu/bg c/ICCT/pdf/CN\%20presentat ions.pdf.

Donoghue, M. R. 2009. Reading: Principles, approaches, comprehension, and fluency. In Language arts: Integrating skills for classroom teaching. (pp. 157-201). Thousand Oaks, CA: SAGE Publications, Inc. doi:

http://dx.doi.org/10.4135/978 1452274799.n6

Dornye,Z. 2003. Questionnaires in Second Language Research: constructing, administration, and processing. New Jersey: Lawrence Erlbaum Associates Publisher.

Easwaramoorthy, M. \& Zarinpoush, F. 2006. Interviewing for Research. Imagine Canada. Retrieved from: http://sectorsource.ca/sites/def ault/files/resources/files/tipshe et6_interviewing_for_research _en_0.pdf.

Education Department. 2001. The Use of Graphic Organizers to enhance Thinking Skills in the Learning of Economics. Honkong . Retrieved from http://ebook.lib.hku.hk/HKG/ B35846288.pdf

Gerbé, O., \& Perron, M. 1995.

Presentation Definition Language Using Conceptual
Graphs. In Peirce Workshop Proceedings. Retrieved from: http://citeseerx.ist.psu.edu/vie wdoc/download?doi=10.1.1.8 7.5293\&rep=rep1\&type pdf.

Hall, T., \& Strangman, N. 2002.

Graphic organizers.

Wakefield, MA: National

Center on Accessing the General Curriculum.

Retrieved [insert date] from http://aim.cast.org/learn/histor yarchive/backgroundpapers/gr aphic_organi.

Hamra, A., \& Syatriana, E. 2010.

Developing A Model of

Teaching Reading

Comprehension for EF

Students. TEFLIN Journal, 21 (1), 27-40.

Hill, S., \& Launder, N. 2009.

Connections between oral language and beginning reading. Reading Research Quarterly, 43(2), 103-130.

Juel. C. 1988. Learning to Read and Write: A longitudinal Study of 54 Children from First Through Fourth Grades. Journal of Educational Psychology, 80(4), 437-447.

Joyce, B., Weil, M., \& Calhoun, E. 2000. Models of Teaching $\left(6^{\text {th }}\right)$. Boston Pearson Education Company.

Kang, S. 2004. Using Visual Organizers to Enhance EFL Instruction. ELT Journal, 58 (1), 58-67.

Konza, D. 2011. Research into Practice : Understanding the 
Reading Process. Retrieved from :

http://www.decd.sa.gov.au/li teracy/files/links/link_15752 9.pdf

Konza,. D. (2011) Research into Practice: Oral Language. Retrieved from: http://www.decd.sa.gov.au/li teracy/files/links/link_15752 9.pdf.

Mackey, A., \& Gass, S,M. 2005.

Second Language Research: Methodology and design. New Jersey: Lawrence Erbaum Associates, Publisher.

Mazdayasna, G. 2012. Objective Assessment of Oral Presentation and EFL Learners' Speaking Development. Sheikhbahaee EFLO Journal, 1 (2), 23-38

Miles, R. 2000. Oral Presentations for English Proficiency Purposes. Reflections on English Language Teaching, 8 (2), 103-110.

Mohammadi, M., Moenika, M., \& Babelan, A,Z. 2010. The Role of Advance Organizer on English Language Learning As A Second Language. Procedia Social and Behavioral Sciences, 2 ( ). 4667-4671.

Muaka, A., Bernhardt, E.B., \& Kamil, M.L. 2003. Teaching Reading (Vol.2). Brussels. Belgium. International Academy of Education.
North Central Regional Education Laboratory (NCREL). 1995. Strategic Teaching and Reading Project Guidebook. Retrieved from http://imet.csus.edu/imet9/281 /docs/adv_gos_redu.pdf.

Ozturk, O. 2012. The Effects of Graphic Organizers on Reading Comprehension Achievement of EFL learners. Pammukale University Journal of Education, 32 (2), 37-45.

Saldana, J. 2013. The Coding Manual for Qualitative Researchers ( $2^{\text {nd }}$ Ed). London: Sage Publication, Ltd.

Sharifi, R,B. 2013. Graphic

Organizers and Reading Comprehension Ability: Evidence from Iranian EFL University Students. Sino- US English Teaching, 10(5), 358365.

The Learning Centre, The University of New South Wales. 2010. Oral Presentation: for Tutorials \& Seminar. Retrieved from http://www.lc.unsw.edu.au/o nlib/pdf/seminar.pdf

Timothy P. G, 2009. Visual Impact, Visual Teaching $\left(2^{\text {nd }} E d\right)$ : Using images to strengthen learning. Retrieved from http://www.uk.sagepub.com/ upm-data/27832_Ch_1.pdf

Wren, S. 2009. Lesson for Building Decoding Efficiency. Retrieved from 
http://www.balancedreading. com/Word_Work_Overview. pdf.

Ylvisaker, M., Hibbard, M., \&

Timothy, F, T. 2006.

Advance Organizers. New

York. Retrieved from

http://www.projectlearnet.or g/tutorials/advance_organize

rs.html

Yunus, M, M., Saleh, H., \& Johon,

D,S,A. 2013. Using Visual

Aids as a Motivational Tool

in Enhancing Students'

Interest in Reading Literary

Texts. arXiv preprint

arXiv:114 - 117. 